\title{
Studying stirred yogurt microstructure using optical microscopy: How smoothing temperature and storage time affect microgel size related to syneresis
}

\author{
A. Gilbert, ${ }^{1,2}$ L.-E. Rioux, ${ }^{1,2}$ D. St-Gelais, ${ }^{1,3}$ and S. L. Turgeon ${ }^{1,2 *}$ (i) \\ ${ }^{1}$ Department of Food Sciences, Université Laval, Quebec City, QC, Canada, G1V 0A6 \\ ${ }^{2}$ STELA Dairy Research Centre and Institute of Nutrition and Functional Foods, Université Laval, Québec City QC, Canada, G1V 0A6 \\ ${ }^{3}$ Saint-Hyacinthe Research and Development Centre, Agriculture and Agri-Food Canada, Saint-Hyacinthe, QC, Canada, J2S 8E3
}

\begin{abstract}
A grainy texture and high syneresis are 2 defects in low-fat stirred yogurt that are often disliked by consumers. In this study, a rheometer controlling the shear rate and temperature was used to simulate the smoothing step of yogurt manufacture. Identical formulations containing whey protein isolate or whey protein concentrate were compared. After the yogurt milk underwent heat treatment, inoculation, and fermentation at $42^{\circ} \mathrm{C}$, the yogurt was smoothed at $42^{\circ} \mathrm{C}(\mathrm{Y} 42)$ or $20^{\circ} \mathrm{C}(\mathrm{Y} 20)$ or during a cooling ramp from $42^{\circ} \mathrm{C}$ to $20^{\circ} \mathrm{C}$ (YR). Induced syneresis (serum expelled by centrifugation) was measured on d 3. Sizes of microgels (dense protein aggregates) were investigated on d 0,4 , and 7 by laser diffraction and by image analysis using optical microscopy. Optical microscopy was also used to characterize the reorganized protein network embedding microgels. The type of whey protein ingredient had only a slight effect on the induced syneresis of YR and Y20 treated yogurts, and the major effect came from the smoothing temperature. The Y42 treatment presented the highest induced syneresis; YR and Y20 had similar low induced syneresis values. Images showed a heterogeneous microstructure (large microgels, reorganized gel) and serum separation for Y42; the YR and Y20 networks were homogeneous. Both the image analyses and laser diffraction showed that the microgel size depended on the smoothing temperature. However, only the image analyses made it possible to identify a time dependency effect on microgel size during storage. The number of microgels $>10^{4} \mu \mathrm{m}^{2}$ continued to increase over time, whereas the number of microgels $<10^{3} \mu \mathrm{m}^{2}$ decreased. Microscopic observations were less destructive than la-
\end{abstract}

Received April 11, 2019.

Accepted November 3, 2019.

*Corresponding author: Sylvie.Turgeon@fsaa.ulaval.ca ser diffraction and highlighted the presence of microgel aggregation during storage.

Key words: stirred yogurt, microgel particle, syneresis, whey protein

\section{INTRODUCTION}

In recent decades, yogurt has become one of the most emblematic dairy products (Aryana and Olson, 2017), supported by a healthy marketing image (Isaacs, 2016; Aryana and Olson, 2017). Removing fat from stirred yogurt leads to product defects such as reduced perception of creaminess, a grainy texture, increased wheyingoff during storage, and product heterogeneity (Cayot et al., 2008; Krzeminski et al., 2013). Among the solutions proposed to increase firmness and reduce syneresis in nonfat yogurts, the addition of whey protein powders to reduce the casein:whey protein ratio has proven to be efficient (Sodini et al., 2004). Whey protein isolate (WPI) and whey protein concentrate (WPC) have been shown to have different effects on yogurt gel properties (Delikanli and Ozcan, 2014). However, in most studies, the major bias is the composition of the yogurt milk, which is not completely standardized, especially for DM content (Karam et al., 2013), a variable known to affect yogurt functionality (Sodini et al., 2004; Lee and Lucey, 2010).

The steps in the yogurt stirring operation are also known to affect gel functionality. Afonso and Maia (1999) and Guénard-Lampron et al. (2019) found that the smoothing and cooling step performed with a plate heat exchanger was responsible for major changes in viscosity, elasticity, and firmness throughout the process. Moreover, when the gel was smoothed at $38^{\circ} \mathrm{C}$ versus $20^{\circ} \mathrm{C}$, the yogurts were firmer (Guénard-Lampron et al., 2019). Viscosity and firmness are related to the stirred yogurt microstructure, which depends on interactions between molecules or particles (van Marle, 1998; Zoon, 2003; Mokoonlall et al., 2016). According 
to Mokoonlall et al. (2016), one of the major effects comes from the level of gel disruption induced by shear.

During shearing and smoothing, set yogurt is disrupted (broken down), decreasing the viscosity and elasticity of the gel (Mokoonlall et al., 2016). Denser clusters of aggregated proteins from set yogurt gel measuring 10 to $250 \mu \mathrm{m}$, and sometimes $>1 \mathrm{~mm}$, may remain (van Marle, 1998; Küçükçetin et al., 2009; Krzeminski et al., 2011; Körzendörfer et al., 2018). Mokoonlall et al. (2016) defined those clusters as microgels, and van Marle (1998) described them as a substructure composed of primary aggregates interacting with each other. This idea was also investigated by Rasmussen et al. (2007), who showed that smoothing low-fat yogurt with a small-size filter (screen size $<100 \mu \mathrm{m}$ ) led to more aggregation of microgels. According to the literature, intense shearing produces more gel breakdown, leading to small microgels and low yogurt viscosity (Barnes, 1997; Mokoonlall et al., 2016), whereas large and dense microgels $(>150 \mu \mathrm{m})$ have been related to a coarse texture (Cayot et al., 2008; Krzeminski et al., 2013). As well, van Marle (1998) and Körzendörfer et al. (2018) found a relationship between larger microgels and higher induced syneresis results, suggesting that microgel size and syneresis are related. After shearing, the gel rebodying occurs during cold storage: the broken gel structure is modified, new structures build up, and yogurt viscosity increases (Cayot et al., 2003; Renan et al., 2008, 2009). Some authors have introduced the idea that microgels may affect stirred yogurt viscosity depending on their characteristics and interactions in the gel network. However, these studies did not describe changes in the microgels occurring during storage, or their role in rebodying (van Marle, 1998; Zoon, 2003; Mokoonlall et al., 2016). To our knowledge, no studies have looked at how rebodying of stirred yogurt translates in terms of microstructure.

Many techniques are available to study microgel size and stirred gel structure. Traditionally, microgel size is studied using laser diffraction or light scattering (Krzeminski et al., 2011; Nöbel et al., 2016; Zhang et al., 2016; Körzendörfer et al., 2018), whereas stirred yogurt microstructure is observed by confocal laser microscopy (Lee and Lucey, 2006). Sieving techniques can also be used (van Marle, 1998), but major improvements in image analysis have recently been made. Yogurts can be observed at different scale lengths (from micrometers to a few centimeters; Körzendörfer et al., 2018; Moussier et al., 2019), and each technique involves a specific sample preparation method (yogurt diluted in water or spread inside a controlled spacer; van Marle, 1998; Küçükçetin et al., 2009). Image analysis makes it possible to extract different structural indices (such as microgel size and circularity) from the images and even to characterize gel roughness (Küçükçetin et al., 2009; Moussier et al., 2019).

In the present study, the smoothing step was modeled in a rheometer under different temperature conditions. We compared the contributions of WPC and WPI to yogurt properties using formulations calculated to provide identical standardization (total solids, protein content, casein:whey protein ratio). The objective of the study was to use a technique for characterizing yogurt microstructure at the micron to millimeter scale to understand how smoothing temperature, whey protein ingredient, and storage time affect microgel structure and syneresis in stirred yogurt.

\section{MATERIALS AND METHODS}

\section{Yogurt Making}

Milk Preparation. Raw skim milk was provided by Agropur (Saint-Hyacinthe, QC, Canada). Two yogurt milk formulations were prepared with skim milk powder (Agropur, Longueuil, QC, Canada), lactose (Crino lactose; Agropur), and either WPC at 35\% protein content (Agropur) or WPI concentrated at 98\% whey protein (BiPRO; Davisco Foods Intl., Eden Prairie, $\mathrm{MN})$. The target composition for both nonfat yogurts was $14 \%$ total solids, $4 \%$ total protein, and a casein: whey protein (CN:WP) ratio of $2.8: 1$.

Under stirring, the powders were mixed with raw milk for $2 \mathrm{~h}$ at room temperature and then stored at $4^{\circ} \mathrm{C}$ overnight for rehydration. Before heat treatment, the yogurt milks were warmed to $44^{\circ} \mathrm{C}$ for at least 1 h. The yogurt milks were heat-treated in a laboratoryscale system (Figure 1), where the flow rate was adjusted to heat the milks at $94^{\circ} \mathrm{C}$ for approximately 6 min and then quickly cool them to below $10^{\circ} \mathrm{C}$. The heat-treated milks were then collected in sterilized glass bottles to minimize cross-contamination and stored at $4^{\circ} \mathrm{C}$ until use.

Yogurt Starter Preparation. A 12\% (wt/wt) skim milk powder solution was sterilized at $120^{\circ} \mathrm{C}$ for $10 \mathrm{~min}$ and inoculated at $0.1 \%$ with a commercial freeze-dried non-ropy starter, Yo-Dolce 1 (Biena, Saint-Hyacinthe, QC, Canada), composed of Streptococcus thermophilus and Lactobacillus delbrueckii ssp. bulgaricus at a 95:5 ratio. Fermentation took place at $41.0 \pm 0.05^{\circ} \mathrm{C}$ (Isotemp Incubator 200 series, model 230D; Fisher, Toronto, ON, Canada), and $\mathrm{pH}$ was regularly monitored using an SB20 SympHony pH meter (VWR, Mississauga, ON, Canada). When the $\mathrm{pH}$ reached $4.60 \pm 0.05$, the preculture was stored at $4^{\circ} \mathrm{C}$ and then used the following day.

Yogurt Fermentation. Each heat-treated yogurt milk was warmed to $42^{\circ} \mathrm{C}$, inoculated with $5 \mathrm{~mL}$ of preculture, distributed in $20-\mathrm{mL}$ aliquots, and fermented 


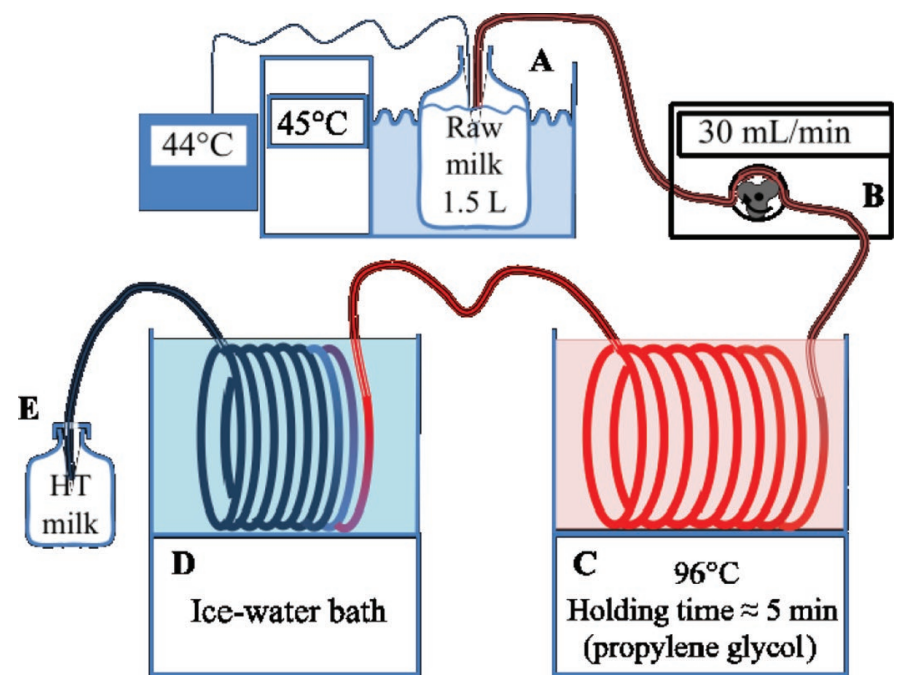

Figure 1. Laboratory-scale heat treatment system for yogurt milk: (A) warming at $44^{\circ} \mathrm{C}$ in a water bath $(1 \mathrm{~h})$; (B) lobe pump set at 30 $\mathrm{mL} / \mathrm{min}$; (C) stainless steel tubing coil in a propylene glycol bath at $96^{\circ} \mathrm{C}$; (D) stainless steel tubing coil in an ice-water bath; and (E) heattreated (HT) milk in a sterilized bottle.

at $41.1 \pm 1.2^{\circ} \mathrm{C}$ (Isotemp Incubator 200 series, model 230D; Fisher). Fermentation lasted for 195 to 225 min until pH $4.60 \pm 0.05$ was reached. Two aliquots were placed inside $30 \mathrm{~mL}$ syringes $(30 \mathrm{~mm}$ diameter; modified by cutting the tip), covered with aluminum foil to avoid evaporation, and placed vertically inside the fermentation oven (Supplemental Figure S1; https:// doi.org/10.3168/jds.2019-16787).

Smoothing Process. The smoothing process simulation was based on the findings of Afonso et al. (2003) and Fernandes et al. (2005). When flowing through a plate heat exchanger, yogurt can be considered a fluid with a laminar flow, and the mean shear rate ranges from 50 to $1,800 \mathrm{~s}^{-1}$, depending on the spatial point of measurement. In the present study, a shear rate of $625 \mathrm{~s}^{-1}$ was chosen to break and smooth the yogurt gel using a rheometer (ARES-G2; TA Instruments, New Castle, DE) equipped with a cup-and-vane geometry (cup diameter $30.32 \mathrm{~mm} ; 4$ blades vane $30 \mathrm{~V}$ diameter $28.04 \mathrm{~mm}$; vane length $27.7 \mathrm{~mm}$ ). The rheometer cup was brought to the desired temperature $\left(20^{\circ} \mathrm{C}\right.$ or $\left.42^{\circ} \mathrm{C}\right)$, and then $40 \mathrm{~mL}(2 \times 20 \mathrm{~mL}$ aliquots $)$ of yogurt was carefully loaded into the cup using the cut syringe system, and the sample was extruded through a 2-mm plastic screen (Supplemental Figure S1). To equilibrate the yogurt temperature in the cup, a preshear step (30 $\mathrm{s}$ at $50 \mathrm{~s}^{-1}$ ) was performed, followed by a smoothing step carried out at a shear rate of $625 \mathrm{~s}^{-1}$ for $5 \mathrm{~min}$. Three temperatures were tested: 2 constant smoothing temperatures $\left[42^{\circ} \mathrm{C}(\mathbf{Y 4 2})\right.$ or $\left.20^{\circ} \mathrm{C}(\mathbf{Y 2 0})\right]$ and a cooling ramp of $0.073^{\circ} \mathrm{C} / \mathrm{s}$, which brought the yogurt samples from $42^{\circ} \mathrm{C}$ to $20^{\circ} \mathrm{C}$ during the smoothing step (YR). The yogurt was then immediately removed from the cup, divided into aliquots, and stored at $4^{\circ} \mathrm{C}$ for later use.

Apparent viscosity and temperature during the smoothing step were recorded over time using the rheometer software (Trios; TA Instruments). Apparent viscosity values were statistically compared only between YR and Y20 at the end of the process, when both samples were at exactly $20^{\circ} \mathrm{C}$.

\section{Yogurt Milk Analyses}

Composition Analyses. All composition analyses (solids, fat, ash, and protein contents) were performed on raw milk (AOAC International, 2012). Whey protein content and $\mathrm{CN}$ :WP ratios were measured using SDS-PAGE in reducing conditions to take into account the denatured WP from powdered ingredients, which cannot be measured by solubility at $\mathrm{pH}$ 4.6. The $2 \times$ reducing buffer was prepared as detailed by the supplier $(2 \times$ Laemmli Sample Buffer; Bio-Rad, Mississauga, ON, Canada) and was mixed at a 1:1 ratio with the milk samples. Samples $(14 \mu \mathrm{g})$ were loaded into precast 4 to $20 \%$ polyacrylamide gels (Mini-Protean TGX Gels; Bio-Rad). Repeatability between gels was validated by loading a milk protein standard $(6 \mu \mathrm{g})$ in each gel. The milk protein standard contained the reducing sample buffer and purified $\alpha_{\mathrm{S}^{-}} \mathrm{CN}, \beta-\mathrm{CN}, \kappa-\mathrm{CN}$, $\alpha-\mathrm{LA}$, and $\beta$-LG (Sigma-Aldrich, St. Louis, MO). Gel imaging was performed with a ChemiDoc XRS system (Bio-Rad), and protein band intensities were quantified with Quantity One 4.5.2 software (Bio-Rad).

The yogurt milk mineral composition was measured in duplicate by first dissolving ash in a $20 \%$ (wt/wt) trichloroacetic acid solution. Each solution was analyzed in triplicate by inductively coupled plasma spectrometry (Optima 4300DV; Perkin-Elmer, Waltham, MA) using wavelengths of 213.617 and $214.914 \mathrm{~nm}$ for phosphorus measurement and 317.933, 315.887, and $422.673 \mathrm{~nm}$ for calcium measurement.

Particle Sizes in Raw and Heat-Treated Milk. The particle size of milk was measured by light scattering spectroscopy using a Zetasizer (Nano series; Malvern Ltd., Malvern, UK). Raw yogurt milk and heat-treated yogurt milk samples were diluted in neutral milk permeate $(100 \mu \mathrm{L}$ of milk into $10 \mathrm{~mL}$ of permeate).

Milk permeate was prepared using a $10 \mathrm{kDa}$ ultrafiltration membrane (DESAL membrane, PW2540F1074; GE Water and Process Technologies, Oakville, ON, Canada) from skim milk purchased in a local grocery store. Sodium azide (EMD, Philadelphia, PA) was added as an antibacterial agent at $0.02 \%$ (wt/wt). Then, the permeate was split into 2 batches: one was 
left at neutral $\mathrm{pH}$ and the other was acidified to $\mathrm{pH}$ $4.60 \pm 0.05$ using hydrochloric acid for yogurt particle size analyses.

\section{Analyses of Stirred Yogurt}

Induced Syneresis Measurement. Induced syneresis measurements were carried out according to Hess et al. (1997) with some modifications. Because the yogurt samples were small, induced syneresis was not measured during storage. At d 3 after production, samples were weighed, equilibrated at $10^{\circ} \mathrm{C}$ for $2 \mathrm{~h}$, and then centrifuged at $10^{\circ} \mathrm{C}$ at $238 \times g$ for $10 \mathrm{~min}$ (Eppendorf centrifuge 5804R V3.3; Mississauga, ON, Canada). The expelled serum was collected and weighed. Syneresis was calculated using the ratio between the expelled serum and the yogurt mass.

Particle Size Measurement. On d 0, 4, and 7 after production, the stirred yogurt particles were analyzed by predispersing $1 \mathrm{~g}$ of yogurt in $10 \mathrm{~mL}$ of acidified milk permeate. The predispersion was carried out at $450 \mathrm{rpm}$ for $15 \mathrm{~min}$ using a small magnetic stirrer into a 20-mL glass beaker. A few drops of this dispersion were transferred into the laser diffraction particle analyzer unit (Mastersizer 3000; Malvern Ltd.) filled with acidified milk permeate and set at $1000 \mathrm{rpm}$. The dispersant refractive index was set at 1.34 , and the particles refractive index was set at 1.46. Particle size was analyzed by means of 5 consecutive measurements under stirring at $1,000 \mathrm{rpm}$ at $20^{\circ} \mathrm{C}$. Three replicates were performed for each sample.

Optical Microscopy. A microscopic image analysis method was developed based on the studies by Küçükçetin et al. (2009) and Körzendörfer et al. (2018), who worked with real-scale images (74 and 171 pixels $/ \mathrm{cm}$, respectively), although an image scale of $100 \mu \mathrm{m}$ was used in this study $(15,198$ pixels $/ \mathrm{cm})$. On $\mathrm{d} 0,4$, and 7 after production, approximately $0.5 \mathrm{~mL}$ of stirred yogurt was transferred to a microscopy slide $(2.5 \mathrm{~cm} \times$ $7.5 \mathrm{~cm})$ equipped with 2 microscope cover glasses $(2.5$ $\mathrm{cm} \times 2.5 \mathrm{~cm} \times 0.175 \pm 0.015 \mathrm{~mm}$ ) fixed with nail polish at each extremity. This created an area of $2.5 \mathrm{~cm} \times$ $2.5 \mathrm{~cm}$ with an average thickness of $0.175 \pm 0.015 \mathrm{~mm}$ where the yogurt was spread. Two slides were prepared for each yogurt. As soon as the yogurt microscopy slides were prepared, they were observed using an optical microscope (Olympus BX51; Olympus, Center Valley, PA) with a $10 \times$ objective. Five random gray images (resolution $300 \mathrm{dpi}$ ) were taken using an adapted camera (Photometrics CoolSNAPfx; Roper Scientific, Ottobrunn, Germany). This technique allowed us to see differences in gel density on the microscopic slides. The light goes through the slides in areas filled with loose (or no) gel, but is blocked by dense compact gel.
When the zone is darker, the gel is denser. The darkest shapes on the images were considered intact aggregated clusters (gel fragments) from the set yogurt (microgels), and their surface areas were measured by image analyses using ImageJ2 software (Küçükçetin et al., 2009; Rueden et al., 2017; https://imagej.net/ImageJ). The threshold adjustment was defined as the percentile pattern of gray. Images were then bipolarized, and the watershed process was applied to differentiate particles from one another (Supplemental Figure S2; https://doi .org/10.3168/jds.2019-16787). Particles under $210 \mu \mathrm{m}^{2}$ (limit of detection determined using glass microspheres of diameter between 15 and $150 \mu \mathrm{m}$; Quality Audit Standards, Malvern Ltd.) and on the border of images were not taken into account. First, the mean particle surface area was measured for each image. Then, the sum of the number of particles found in each image (10 per yogurt sample) was determined and presented according to 4 surface area classes: $<10^{3} \mu \mathrm{m}^{2}$ (i.e., small

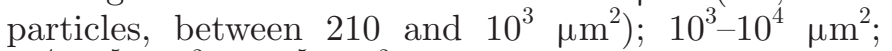
$10^{4}-10^{5} \mu \mathrm{m}^{2} ;>10^{5} \mu \mathrm{m}^{2}$. The 2 last classes were also used to measure the proportion of the surface area occupied by particles larger than $10^{4} \mu \mathrm{m}^{2}$. Particles were also characterized by their circularity index, which is defined in ImageJ2 as circularity index $=(4 \pi \times$ particle area) $/(\text { particle perimeter })^{2}$. This index varies between 0 (noncircular shape) and 1 (perfect circular shape; Moussier et al., 2019). The protein network heterogeneity was also determined based on the study by Küçükçetin et al. (2009), who characterized the visual roughness of stirred yogurt using gray-level variation on images. Each pixel on the images has a gray value between 0 (black) and 255 (white), corresponding to the protein network. Values close to 0 represent a dense protein network at the pixel location, whereas white pixels represent the lack of a protein network. The gray-value histogram represents gray-level distribution on the total image area. This distribution characterizes the protein network density variation on each image. Therefore, the network heterogeneity index (NHI) was defined as the protein network density heterogeneity and was equal to the standard deviation of the grayvalue distributions on the images (calculated by imageJ2; Supplemental Figure S2). A large NHI indicated a heterogeneous gel network with many areas empty of protein networks.

Bacterial Counts. Stock solutions $\left(10^{-2}\right)$ and 5 more dilutions $\left(10^{-3}, 10^{-4}, 10^{-5}, 10^{-6}, 10^{-7}\right)$ of the yogurts were prepared after fermentation (d 0) in sterilized $0.1 \%$ peptone water (Bacto Peptone; BD Biosciences, Sparks, MD). The counts of lactobacilli (dilution $10^{-4}$ and $10^{-5}$ ) and streptococci (dilution $10^{-6}$ and $10^{-7}$ ) were performed by plate spreading on, respectively, acidified MRS agar medium (EMD Millipore, Billerica, MA) and 
M17 agar medium (Oxoid Ltd., Basingstoke, UK) with added lactose $(0.5 \% \mathrm{wt} / \mathrm{vol})$. Then, the plates were incubated under anaerobic conditions for $4 \mathrm{~d}$ at $37^{\circ} \mathrm{C}$. The counts of lactobacilli and streptococci were similar for each yogurt batch (lactobacilli $3.5 \times 10^{7} \mathrm{cfu} / \mathrm{mL}$; streptococci $\left.1.8 \times 10^{9} \mathrm{cfu} / \mathrm{mL}\right)$.

\section{Experimental Design and Statistical Analyses}

The yogurts were analyzed according to a split-plot design using whey ingredient as the main factor and smoothing temperature as the secondary factor. Because the volumes of production were small, 6 different productions were realized to conduct the experiments on microgel sizes, and the experiments on syneresis were carried out in 3 other independent repetitions (productions). Composition and final apparent viscosity were measured on all 9 repetitions.

The SAS software program, version 9.4 (SAS Institute Inc., Cary, NC), using mixed procedures, was used for the statistical analyses. When measurements were repeated during storage, the best correlation structure was chosen according to the corrected Akaike's information criterion. To satisfy the model hypothesis, some sets of data needed adjustment. When the data set presented a heteroscedasticity issue, 2 error types depending on the WP ingredient were inserted into the model. Classical issues of inhomogeneous variation or non-normal distribution were adjusted by mathematical transformations; the most appropriate one was suggested by the Box-Cox procedure. For particle circularity index, a fourth factor (microgel surface area interval) was included in the model with its own standard deviation. Following a significant effect in the model, multiple comparisons were carried out using the protected Fisher's least significant difference method. The normality assumption was verified using the Shapiro-Wilk statistic, and homogeneity of variances was verified using the plots of the residuals. Results are reported as mean \pm standard error.

\section{RESULTS AND DISCUSSION}

\section{Composition and Protein Particle Sizes in Milks Before Fermentation}

Yogurt milk composition showed no significant differences based on the WP ingredient used (Table 1). We found a slight difference in the $\mathrm{CN}$ :WP ratio between the 2 WP ingredients, but this difference was considered negligible. The ash content was also different $(\Delta$ $0.04 \%$ ) depending on whether the standardization was carried out using WPC or WPI. However, we found no significant differences in the content of calcium and phosphorus, minerals known to affect yogurt properties (Lucey and Horne, 2009; Karam et al., 2013).

Particle size was similar for both raw milks, but a significant difference was induced by heat treatment (Table 1). The heat-treated WPC-enriched milk showed larger particle sizes than the heat-treated WPI-enriched milk. Whey protein aggregates can form in the serum and around the casein micelles when heat treatment is applied (Beaulieu et al., 1999). The size difference between the WPI and WPC milk aggregates was small and may have been related to the initial denaturation level of the WP powders (insoluble protein at $\mathrm{pH} 4.6$ was around $21 \%$ for WPI and $32 \%$ for WPC).

\section{Yogurt Gel Properties}

Apparent Viscosity During Processing. Yogurt apparent viscosity during the process is presented in Figure 2. Only the final viscosities of YR and Y20 were compared statistically. Smoothing temperature was the sole factor affecting final apparent viscosity $(P<$ 0.0001 ), and the whey protein ingredients had no effect (data not shown). For Y42 and Y20, the apparent viscosity values decreased over time and reached an equilibrium value (Figure 2). This indicated non-Newtonian behavior and suggested progressive breakdown of the gel structure (Barnes, 1997; Abu-Jdayil, 2003). As expected, apparent viscosity values were higher at $20^{\circ} \mathrm{C}$ than at $42^{\circ} \mathrm{C}$, as seen in the literature (Benezech and Maingonnat, 1993; Afonso and Maia, 1999; Mokoonlall et al., 2016). The viscosity of a solution is temperaturedependent; it decreases with increasing temperature (Mezger, 2006). For the YR sample, apparent viscosity decreased during the first $50 \mathrm{~s}$ (temperature $41^{\circ} \mathrm{C}$ ), and because the temperature kept decreasing, the apparent viscosity increased. The ingredients (WPC or WPI)

Table 1. Composition and particle size of yogurt milks ${ }^{1,2}$

\begin{tabular}{lcr}
\hline Variable & M-WPI & \multicolumn{1}{c}{ M-WPC } \\
\hline Milk composition & & \\
Total solids content (\%) & $13.84 \pm 0.05^{\mathrm{a}}$ & $13.91 \pm 0.02^{\mathrm{a}}$ \\
Fat content (\%) & $0.19 \pm 0.12^{\mathrm{a}}$ & $0.21 \pm 0.12^{\mathrm{a}}$ \\
Protein content (\%) & $3.82 \pm 0.04^{\mathrm{a}}$ & $3.90 \pm 0.07^{\mathrm{a}}$ \\
Casein:whey protein ratio & $2.85 \pm 0.02^{\mathrm{b}}$ & $2.92 \pm 0.02^{\mathrm{a}}$ \\
Ash (\%) & $0.81 \pm 0.01^{\mathrm{b}}$ & $0.85 \pm 0.01^{\mathrm{a}}$ \\
Calcium (mg/g) & $0.73 \pm 0.06^{\mathrm{a}}$ & $0.70 \pm 0.06^{\mathrm{a}}$ \\
Phosphate (mg/g) & $0.85 \pm 0.04^{\mathrm{a}}$ & $0.84 \pm 0.03^{\mathrm{a}}$ \\
Particle size in milk (nm) & & \\
Raw milk & $191.0 \pm 1.6^{\mathrm{a}}$ & $189.4 \pm 1.6^{\mathrm{a}}$ \\
Heat-treated milk & $204.4 \pm 1.6^{\mathrm{b}}$ & $207.8 \pm 1.6^{\mathrm{a}}$ \\
\hline
\end{tabular}

$\overline{\mathrm{a}, \mathrm{b}}$ Means in a row with different superscripts are significantly different $(P<0.05)$.

${ }^{1}$ All values are expressed as mean $\pm \mathrm{SE}(\mathrm{n}=9)$.

${ }^{2} \mathrm{M}-\mathrm{WPC}=$ milk formulation prepared with whey protein concentrate; M-WPI $=$ milk formulation prepared with whey protein isolate. 
used for the yogurt standardization had no significant effect on final apparent viscosity at $20^{\circ} \mathrm{C}$ for $\mathrm{Y} 20$ or YR (data not shown). During shearing, the yogurt gel undergoes structural breakdowns; that is, the interactions bonds and structures that defined the gel are progressively broken (Abu-Jdayil, 2003; Lee and Lucey, 2006; Abu-Jdayil et al., 2013), leading to the formation of microgels. This translates into a decrease in viscosity during shearing (van Marle et al., 1999; Mokoonlall et al., 2016). Microgel size is one of the factors that may influence yogurt viscosity (van Marle et al., 1999; Zoon, 2003; Mokoonlall et al., 2016) as schematized by Barnes (1997) in a review about thixotropic fluids. For instance, intense shearing leads to the formation of small microgels, producing stirred yogurt with low viscosity (Mokoonlall et al., 2016) because of greater structural breakdown (Abu-Jdayil et al., 2013). This may suggest that shearing temperature influences microgel formation. Guénard-Lampron et al. (2019) compared 2 smoothing temperatures $\left(20^{\circ} \mathrm{C}\right.$ versus $\left.38^{\circ} \mathrm{C}\right)$ for a yogurt stirred with a technical-scale pilot unit. After $1 \mathrm{~d}$ of storage at $4^{\circ} \mathrm{C}$, the yogurts smoothed at $20^{\circ} \mathrm{C}$ were less viscous than the yogurts smoothed at $38^{\circ} \mathrm{C}$, suggesting that the yogurt smoothed at $38^{\circ} \mathrm{C}$ underwent less structural breakdown. According to Tamime and Robinson (2007), when screens, strainers, or structurizers are used to smooth yogurts, a smoothing temperature close to that of coagulum fermentation reduces the pressure needed to have the sample pass through the smoothing device and achieve the necessary flow, reducing the amount of structural breakdown in the gel. Microgel characteristics may have been affected by gel rheological properties that changed depending on the smoothing temperature. Cooling increases gel elasticity (Arshad et al., 1993), resulting in higher shear stresses during smoothing (Mokoonlall et al., 2016). In the current study, we expected that the structure of the YR yogurt was subjected to less structural breakdown than Y20, resulting in larger microgels.

Induced Syneresis. We found a significant interaction on induced syneresis between the whey protein ingredient used for the standardization and the smoothing temperature $(P<0.001$; Figure 3$)$. We observed the effect of the whey protein ingredient for induced syneresis measurements in the YR and Y20 samples only, and the difference averaged $1 \%$. Because
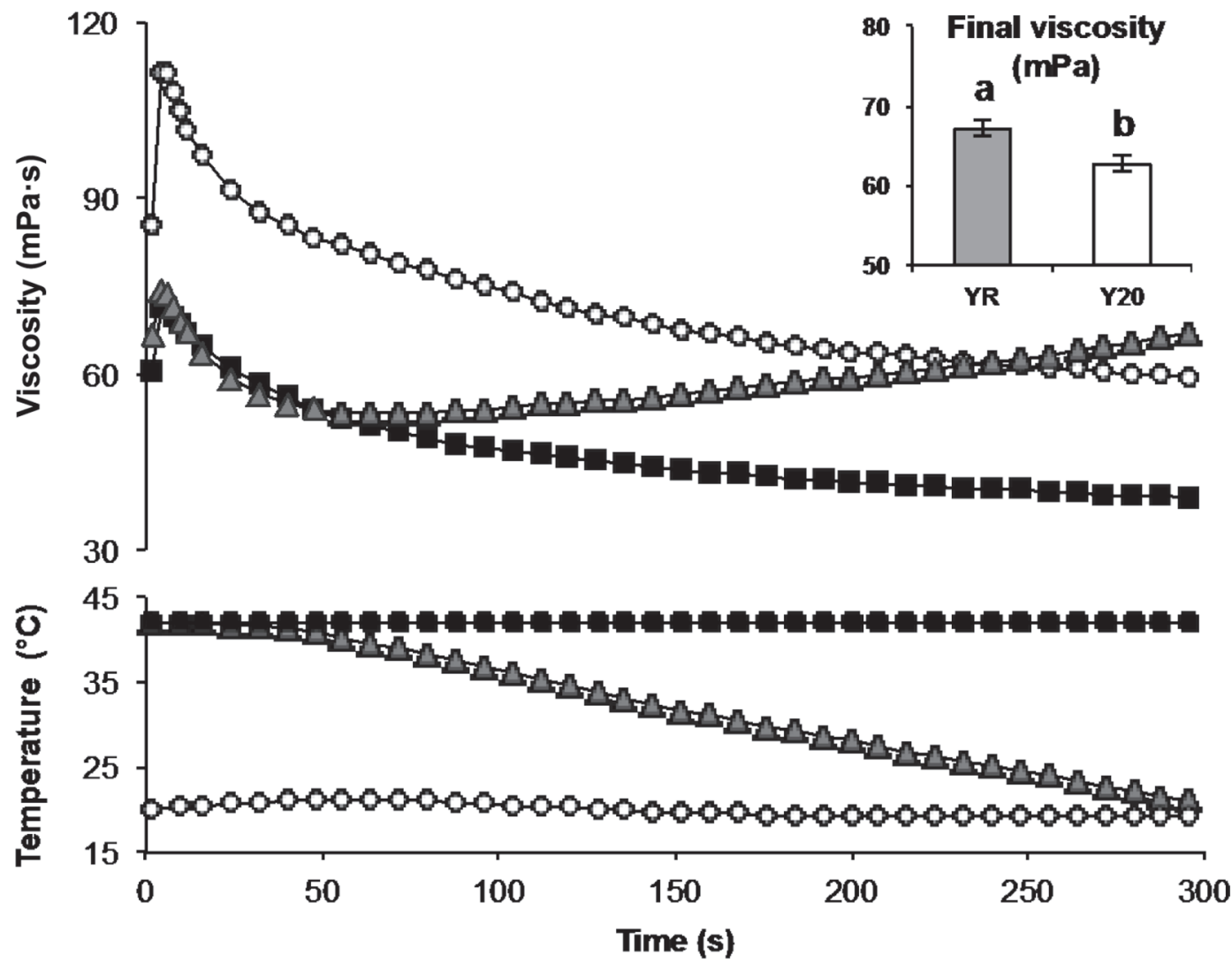

Figure 2. Apparent viscosity measured during yogurt smoothing. The yogurts were smoothed at $20^{\circ} \mathrm{C}$ (white circles, Y20), at $42^{\circ} \mathrm{C}($ black squares, Y42), or during a cooling ramp from $42^{\circ} \mathrm{C}$ to $20^{\circ} \mathrm{C}$ (gray triangles $=42^{\circ} \mathrm{C}$, YR). The histogram in the top right shows the final apparent viscosity data points at $20^{\circ} \mathrm{C}$. Error bars represent the SE $(\mathrm{n}=12)$. Different letters $(\mathrm{a}, \mathrm{b})$ indicate significant differences $(P<0.0001)$. 
a similar effect has not been observed with other methods, interpretation was difficult. When the yogurt was stirred at $42^{\circ} \mathrm{C}$, induced syneresis was highest (Figure $3)$; significantly lower values were found for YR and Y20. In a study by Guénard-Lampron et al. (2019), no differences in induced syneresis were observed, whether the yogurt was smoothed at $38^{\circ} \mathrm{C}$ or $20^{\circ} \mathrm{C}$. In that study, the contribution of each unit operation (stirring, pumping, smoothing, and cooling) to the total change in induced syneresis (as a percentage) was determined. Those authors found that the contribution of the cooling system (plate or tubular heat exchanger) to yogurt induced syneresis at the end of the overall process was higher when the yogurt had been smoothed at $38^{\circ} \mathrm{C}$. The gel structure was not investigated in that study. Other studies reported that intense shearing led to higher syneresis results because it broke interactions and modified structures inside the gel, considerably reducing the number of pores and cavities that can entrap serum (van Marle, 1998; Mokoonlall et al., 2016; Zhang et al., 2016) and creating a looser gel with lower water-holding capacity.

Microgel Size and Structure. All size distributions obtained by laser diffraction were monomodal, and the particle size measurement was not significantly affected by the effect of the storage time or the ingredient. Particle size was affected by yogurt smoothing temperature alone $(P<0.001)$. As shown in Figure 4 , microgels had a significantly larger diameter $\mathrm{D}[4,3]$ (volume-weighted

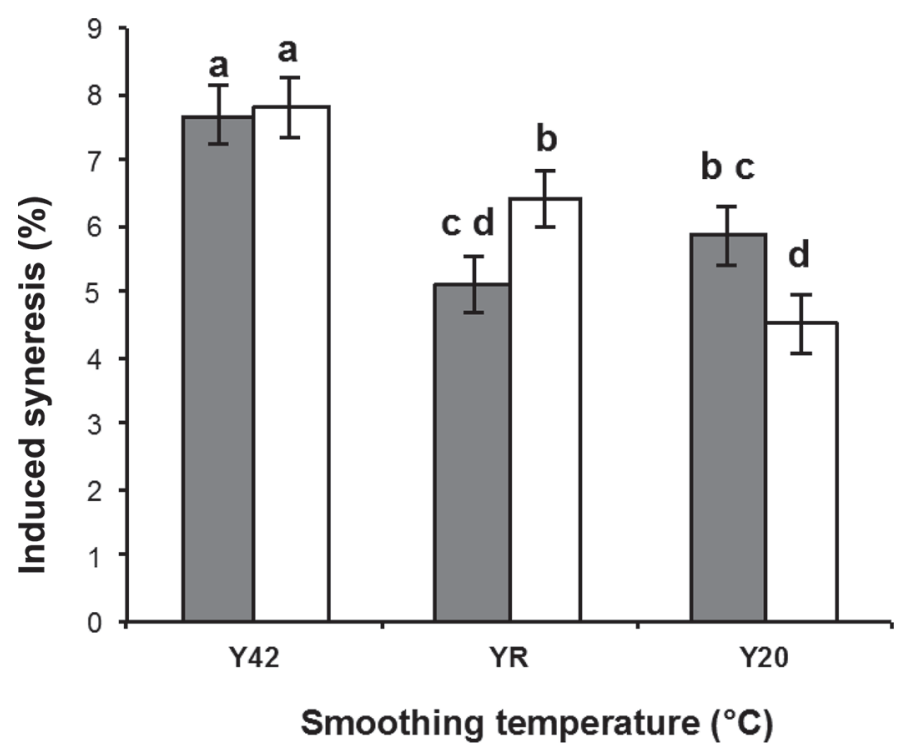

Figure 3. Induced syneresis of stirred yogurts measured after 3 $\mathrm{d}$ of storage. The yogurts were formulated with whey protein isolate (gray bars) or whey protein concentrate (white bars). The yogurts were smoothed at $42^{\circ} \mathrm{C}$ (Y42), during a cooling ramp from $42^{\circ} \mathrm{C}$ to $20^{\circ} \mathrm{C}(\mathrm{YR})$, or at $20^{\circ} \mathrm{C}(\mathrm{Y} 20)$. Error bars represent the $\mathrm{SE}(\mathrm{n}=3)$. Different letters $(\mathrm{a}-\mathrm{d})$ indicate significant differences $(P<0.05)$. mean diameter) in Y42 than in YR or Y20. This result was in accordance with the microscopic observation performed on the stirred yogurts smoothed at different temperatures (Figure 5). At $42^{\circ} \mathrm{C}$, the gel was heterogeneous with abundant large, dense particles (dark gray shapes), and the serum phase seemed to separate (light gray to white areas; Figure 5A, D). The YR and Y20 yogurts looked similar (Figure 5B, C, E, F), with less visible serum and small microgels embedded in a blurry network, probably resulting from gel disruption induced by intense shearing, as previously proposed by Afonso and Maia (1999) and mentioned in Mokoonlall et al. (2016). Indeed, van Marle (1998), using rheological data, mentioned that prolonged intense shearing (over $447 \mathrm{~s}^{-1}$ ) disrupted primary microgels into protein particles. Using a microrheological model, they estimated the hydrodynamic diameter of the protein particles to be under $8 \mu \mathrm{m}$ (approximately $50 \mu^{2}$ if considered circular).

The microgel surface areas measured using image analysis are presented in Figure 6 (discrimination of microgels by image analysis is presented in Supplemental Figure S3; https://doi.org/10.3168/jds.2019-16787). Only the temperature (Figure $6 \mathrm{~A}$ ) and storage time (Figure 6B) had significant individual effects $(P<$ 0.001). Microgel surface area increased with smoothing temperature and storage time. The microgel surface areas of all the yogurts increased significantly (by 200

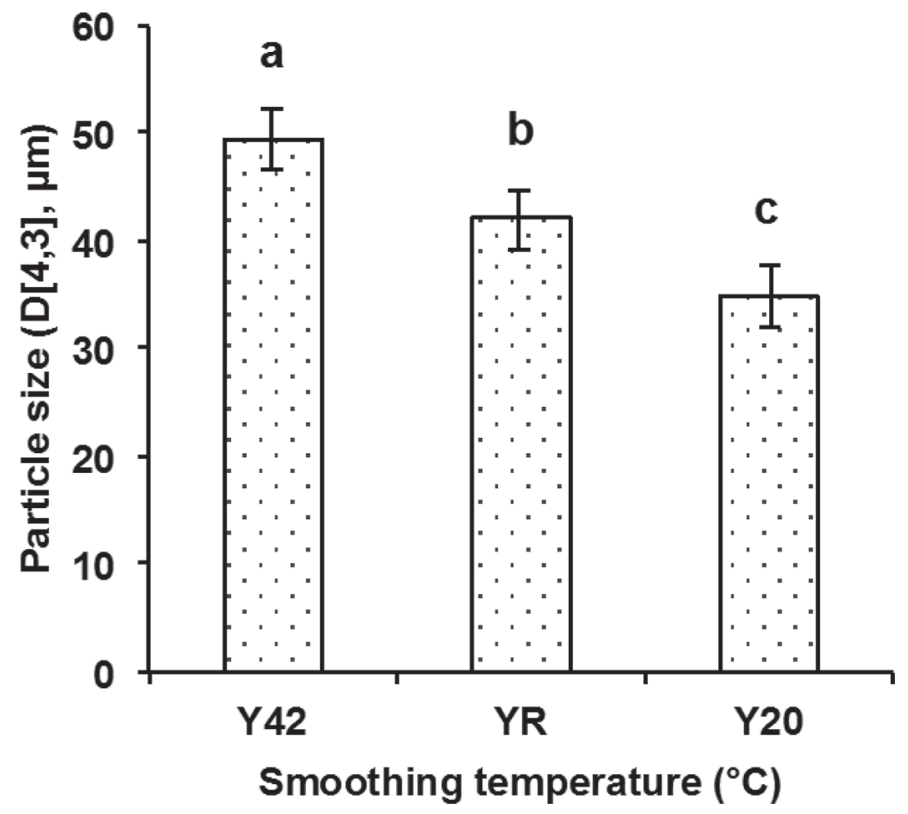

Figure 4. Volume-weighted mean $(\mathrm{D}[4,3])$ of particle sizes from yogurt measured by laser diffraction. The yogurts were smoothed at $42^{\circ} \mathrm{C}$ (Y42), during a cooling ramp from $42^{\circ} \mathrm{C}$ to $20^{\circ} \mathrm{C}$ (YR), or at $20^{\circ} \mathrm{C}$ (Y20). Error bars represent the SE $(\mathrm{n}=36)$. Different letters $(\mathrm{a}-\mathrm{c})$ indicate significant differences $(P<0.001)$. 


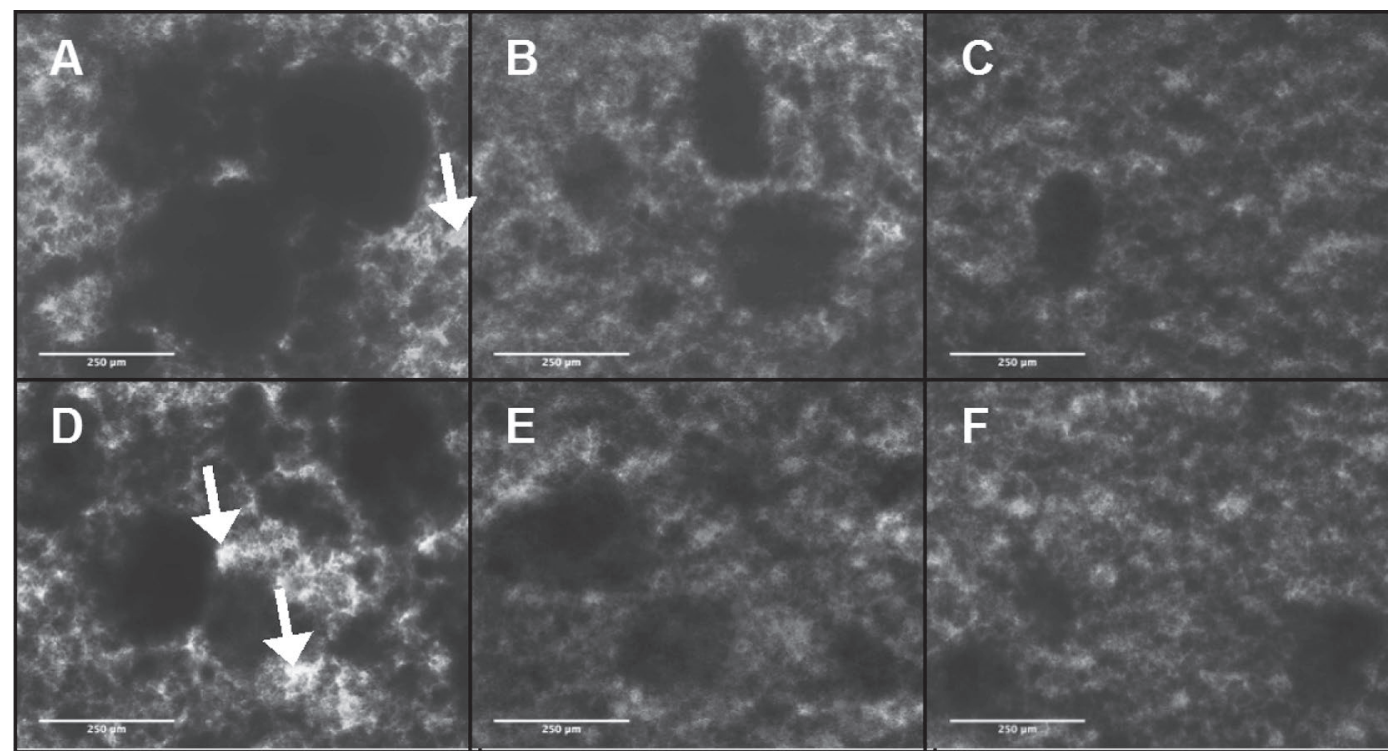

Figure 5. Microscopic images of stirred yogurts after $4 \mathrm{~d}$ of storage. The white scale bar represents $250 \mu \mathrm{m}$. The white arrows show some examples of visible separating serum. The yogurts were smoothed $(\mathrm{A}$ and $\mathrm{D})$ at $42^{\circ} \mathrm{C},(\mathrm{B}$ and $\mathrm{E})$ during a cooling ramp from $42^{\circ} \mathrm{C}$ to $20^{\circ} \mathrm{C}$, or $(\mathrm{C}$ and $\mathrm{F})$ at $20^{\circ} \mathrm{C}$. The yogurt gels were formulated with $(\mathrm{A}, \mathrm{B}$, and $\mathrm{C})$ whey protein isolate or $(\mathrm{D}, \mathrm{E}$, and $\mathrm{F})$ whey protein concentrate.

$\mu \mathrm{m}^{2}$ ) between 0 and $4 \mathrm{~d}$ of storage, whereas between 4 and $7 \mathrm{~d}$, the microgel surface areas were similar. Previous studies showed that stirred yogurt is a suspension of microgels in serum (van Marle, 1998; Zoon, 2003; Mokoonlall et al., 2016; Moussier et al., 2019). However, to study stirred yogurt structure and microgels, some authors used different microscopic methods with smaller-scale images $(\leq 10 \mu \mathrm{m}$; Lee and Lucey, 2006; Moussier et al., 2019) or larger-scale images (real-size scale in mm; Küçükçetin, 2008a; Körzendörfer et al., 2018), and other authors used yogurt diluted in distilled water (van Marle, 1998; Moussier et al., 2019). In the present study, the disrupted yogurt gel was visible because image analyses were performed without dilution of the yogurt. Moreover, the method potentially detects microgel sizes between 210 and $1.4 \times 10^{6} \mu^{2}$ (approximate diameter between $16 \mu \mathrm{m}$ and $1.3 \mathrm{~mm}$ if microgels had a circular shape), which is a wider range than in most image analyses.

The microgel sizes measured by laser diffraction and image analyses were similar. Indeed, if the shape of the microgels was considered a perfect circle, the diameters calculated from the average microgel surfaces of Y42, YR, and Y20 measured by image analysis (Figure 6 -A) were $46.1,39.5$, and $31.7 \mu \mathrm{m}$, respectively. These values were similar to the $\mathrm{D}[4,3]$ found with laser diffraction (Y42: $49.6 \mu \mathrm{m}$; YR: $42.0 \mu \mathrm{m}$; and Y20: 34.7 $\mu \mathrm{m})$ (Figure 4). However, image analysis results are presented as surface area, more representative of the shapes of microgels (which are not circular; circularity index <0.5) than diameters estimated with laser diffraction. Küçükçetin et al. (2011; 2012) were not able to correlate laser diffraction and image analyses, because the minimum yogurt grain diameter detection they calibrated $(>318 \mu \mathrm{m})$ with image analysis ignored the small particles measured by laser diffraction (Mastersizer 2000 particle size detection: $0.02 \mu \mathrm{m}$ to $2 \mathrm{~mm}$ ). However, Moussier et al. (2019) found a correspondence between microgel sizes measured by laser diffraction, 2D dynamic image analysis, and 3D reconstruction from confocal microscopy (scale around $10 \mu \mathrm{m}$ ). It should be underlined that the yogurt samples in that study were diluted for image analysis, which could have modified the shape, size, and aggregation of the microgels in the samples.

Apart from microgel size, because the yogurt was not diluted in the present study, microscopic images were also analyzed using the protein NHI. Microgel surface area measurement focuses on dense microgel size, but the NHI measures differences in gel density in the total image area. The NHI helps characterize how "open" the gel is. Large values for the NHI indicate yogurt with distinctive areas of low-density protein networks, areas filled with serum only, or areas with dense protein networks. Inversely, a large amount of disturbed gel embedding small microgels and no visible serum corresponds to small NHI values. Neither the ingredient nor the storage time changed the NHI values in this study. Only the smoothing temperature had a significant effect on NHI values $(P<0.001$; Figure $6 \mathrm{C})$.

In the present study, image analysis made it possible to observe an increase in microgel size during storage 

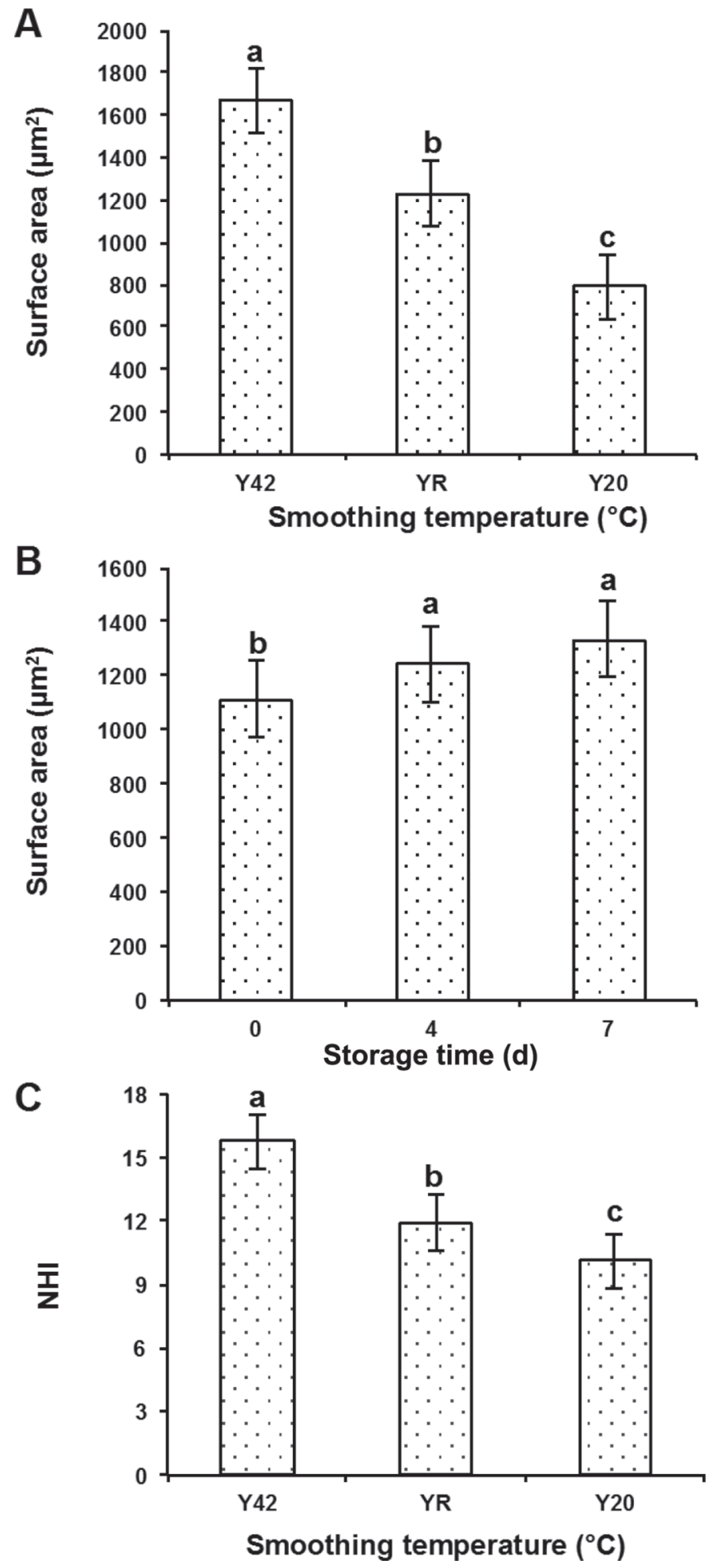

Figure 6. (A and B) Microgel surface area and (C) protein network heterogeneity index (NHI) measured by image analyses. (A and C) The yogurts were smoothed at $42^{\circ} \mathrm{C}$ (Y42), during a cooling ramp from $42^{\circ} \mathrm{C}$ to $20^{\circ} \mathrm{C}$ (YR), or at $20^{\circ} \mathrm{C}$ (Y20). (B) Measurements were taken after 0,4 , and $7 \mathrm{~d}$ of storage. Error bars represent the $\mathrm{SE}(\mathrm{n}=$ 36). Different letters $(\mathrm{a}-\mathrm{c})$ indicate significant differences $(P<0.001)$.
(Figure 6B). That increase could be interpreted as microgel swelling or aggregation. Microgel aggregation leads to the formation of a substructure, as described by van Marle (1998). The fact that the NHI did not change during storage, unlike microgel surface area, could indicate that the protein network density also did not change during storage (no contraction or expansion of the network). This supports the hypothesis that microgels tend to aggregate during storage rather than swell. When laser diffraction is used, samples are diluted and stirred, and this may break down the weakest structures in the gel and hide the microgel aggregation that occurs during storage. Indeed, van Marle (1998) mentioned that aggregated microgels (super microgels) can be broken at shear values as low as $10 \mathrm{~s}^{-1}$. Mellema et al. (2002) also suggested similar changes in the substructure and primary microgels during rennet gel storage. Four levels of structural organization of dairy gel structure were defined: (1) molecular level (micelles and protein interaction); (2) particle level (corresponding to primary microgels); (3) particle cluster level (aggregated microgels in the present study); and (4) macroscopic gel level. Each of those levels of structure can rearrange during storage and possibly aggregate. Microgel aggregation in stirred yogurt during storage may be confirmed by the number of particles found in each image.

Microgel Number, Surface Area, and Circularity Based on Image Analysis. Using image analysis, the number of microgels per milliliter of yogurt was determined for each image and grouped into different surface area classes. Whether the calculation was done for the sum of each class of microgel surface area or individually for each class, the number of microgels was influenced significantly by smoothing temperature (Figure 7A) and storage time (Figure 7B; $P<0.05$ ). The Y20 yogurt had the highest number of microgels when the sum of classes was calculated, but it had the lowest number of large particles $\left(>10^{4} \mu \mathrm{m}^{2}\right.$; Figure 7A). The Y42 and YR yogurts had equivalent total numbers of microgels per milliliter. However, YR had more small microgels $\left(<10^{3} \mu \mathrm{m}^{2}\right)$ than Y42, which contained a higher number of large microgels $\left(>10^{4} \mu \mathrm{m}^{2}\right)$. We observed a change in the number of microgels during storage. The total number of microgels was reduced from $2.0 \times 10^{6}$ to $1.8 \times 10^{6}$ microgels $/ \mathrm{mL}$ of yogurt after $7 \mathrm{~d}$ of storage (Figure 7B). This result is explained by a reduction in the number of small microgels $\left(<10^{3}\right.$ $\mu \mathrm{m}^{2}$ ) and a slight increase in the number of large microgels $\left(>10^{4} \mu \mathrm{m}^{2}\right)$ during storage. These results were in line with the percentage of the image surface occupied by large microgels $\left(>10^{4} \mu \mathrm{m}^{2} ; P<0.01\right.$; Figure 8). In Y 42 and YR, 30\% of the microgel surface areas were occupied by large microgels, which accounted for 
only $11 \%$ of the surface area in Y20 (Figure 8A). During storage, the surface area increased for all yogurts, reaching $27 \%$ after $7 \mathrm{~d}$ (Figure $8 \mathrm{~B}$ ). These results confirm that a high smoothing temperature leads to bigger microgels, which tend to aggregate during storage, resulting in an increase in microgel surface area. Hahn et al. (2012a,b,c) highlighted microgel aggregation due to higher temperatures in cream cheese using laser diffraction and image analysis. Mechanical treatment intensity (shearing) before storage reduced particle (microgel) sizes, whereas the resting temperature and time promoted aggregation. Aggregation kinetics were controlled by resting (tempering) temperature and time. A longer holding time and a higher tempering temperature $\left(45^{\circ} \mathrm{C}\right)$ led to more aggregation (higher particle size) than a short holding time and a low tempering temperature $\left(25^{\circ} \mathrm{C}\right.$; Hahn et al., 2012a,b). To our knowledge, few studies involving stirred yogurt have looked at postprocessing aggregation. Rasmussen et al. (2007) studied yogurt microgel formation using a technical-scale pilot unit equipped with filters of different screen sizes $(50,100$, or $150 \mu \mathrm{m})$ for smoothing $\left(\right.$ at $22^{\circ} \mathrm{C}$ ). Those authors defined the degree of aggregation (measured by laser diffraction) as the volume percentage of microgels bigger than the screen size used to smooth the yogurt. Low-fat yogurt smoothed with small screen sizes showed more microgel aggregation on d 7, in agreement with our results.

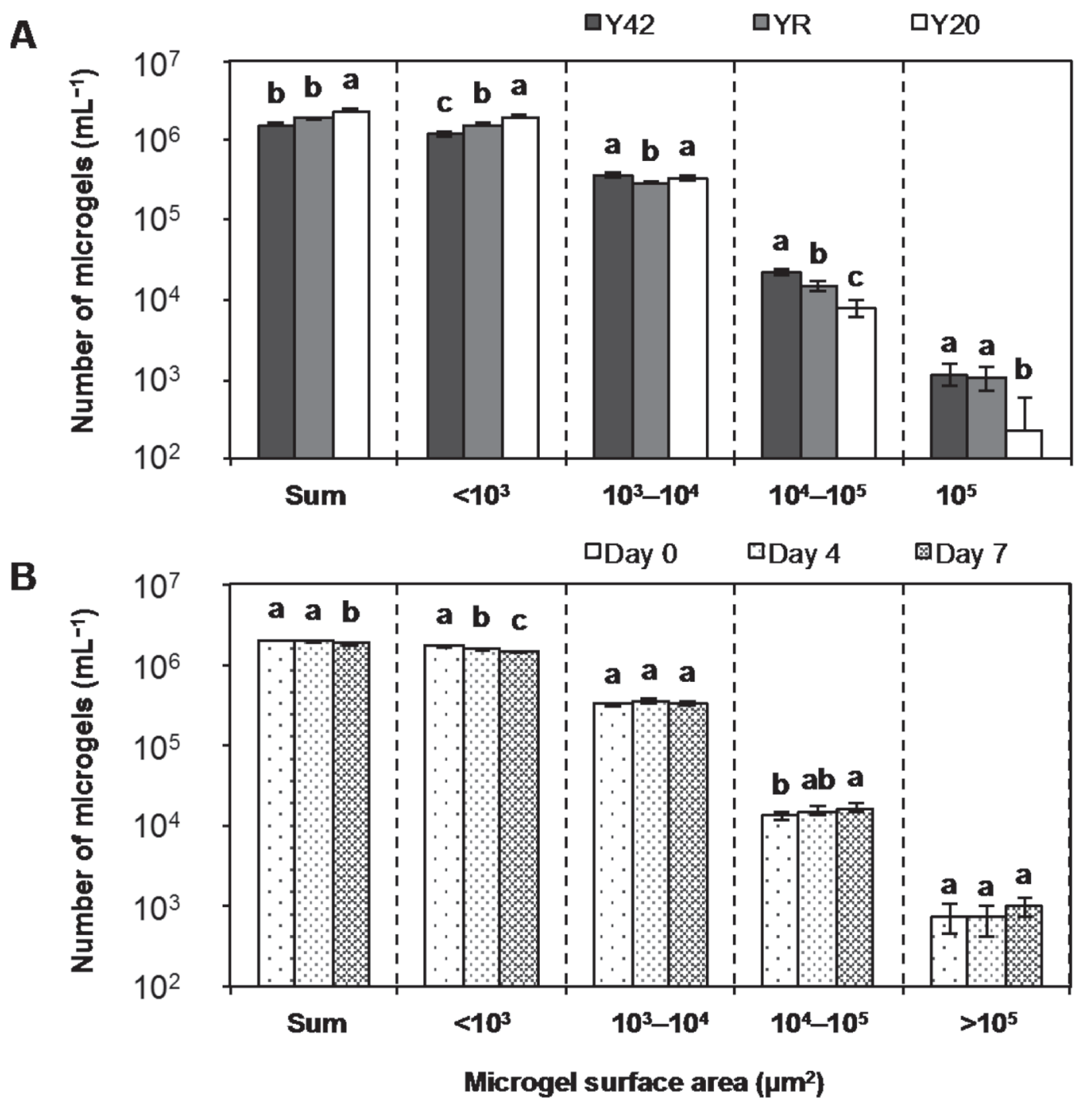

Figure 7. Number of microgels detected per milliliter of yogurt. (A) The yogurts were smoothed at $42^{\circ} \mathrm{C}$ (Y42), during a cooling ramp from $42^{\circ} \mathrm{C}$ to $20^{\circ} \mathrm{C}$ (YR), or at $20^{\circ} \mathrm{C}$ (Y20). (B) Measurements were taken after 0 , 4, and $7 \mathrm{~d}$ of storage. The sum of the number of particles was determined and presented according to 4 surface classes: $<10^{3} \mu \mathrm{m}^{2} ; 10^{3}-10^{4} \mu \mathrm{m}^{2} ; 10^{4}-10^{5} \mu \mathrm{m}^{2} ;$ and $>10^{5} \mu \mathrm{m}^{2}$. Error bars represent the SE $(\mathrm{n}=$ 36). Different letters $(\mathrm{a}-\mathrm{c})$ indicate significant differences within each microgel surface class $(P<0.05)$. 

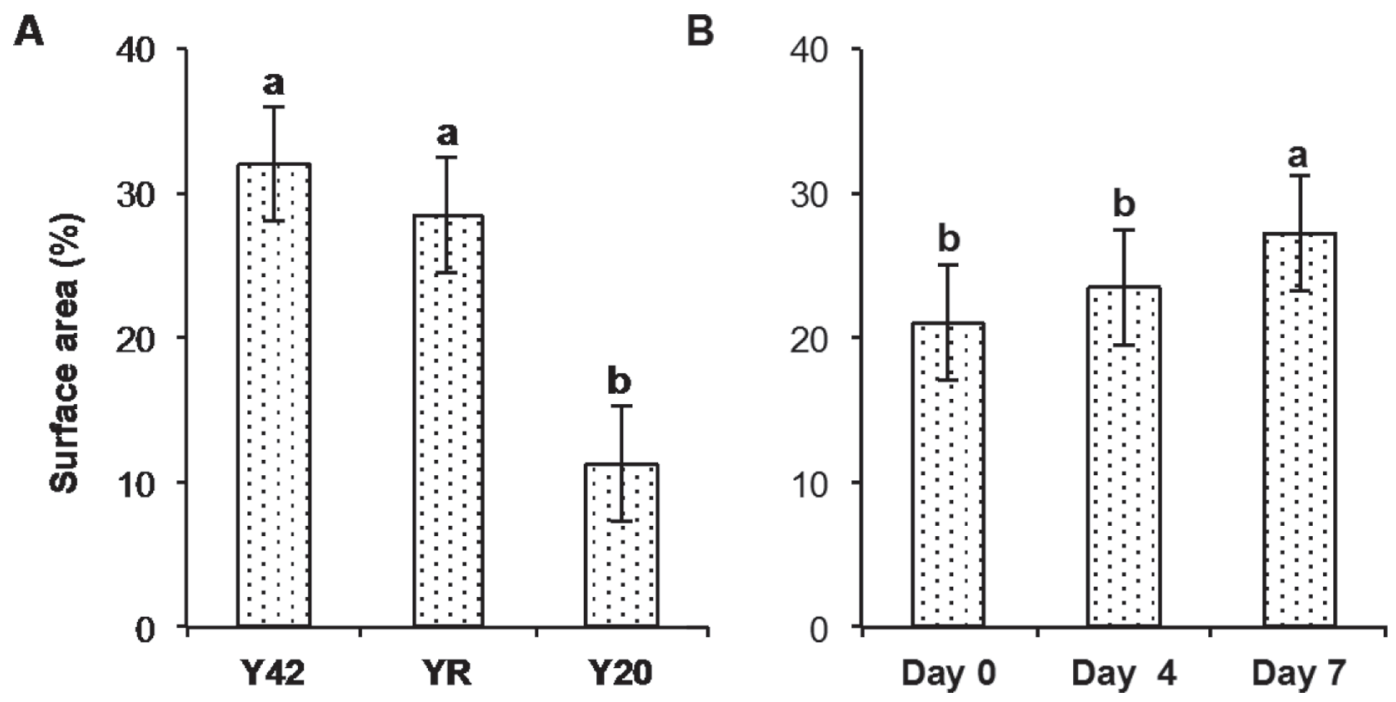

Figure 8. Percentage of the image surface occupied by microgels with a surface area $>10^{4} \mu \mathrm{m}^{2}$. (A) The yogurts were smoothed at $42^{\circ} \mathrm{C}$ (Y42), during a cooling ramp from $42^{\circ} \mathrm{C}$ to $20^{\circ} \mathrm{C}$ (YR), or at $20^{\circ} \mathrm{C}(\mathrm{Y} 20)$. (B) Measurements were taken after 0, 4 , and $7 \mathrm{~d}$ of storage. Error bars represent the SE $(n=36)$. Different letters $(\mathrm{a}, \mathrm{b})$ indicate significant differences $(P<0.01)$.

Microscopic image analysis gives further information on microgel shape through the circularity index, which ranges from 0 (irregular shape) to 1 (perfect circle; Figure 9). We found no significant effect of storage time on the circularity index. The smoothing temperature significantly reduced the circularity index values, but the differences were small, preventing further discussion (Supplemental Figure S4; https://doi.org/10.3168/ jds.2019-16787). However, the circularity of microgels decreased with increasing microgel surface area (Figure 9). Moussier et al. (2019) also found similar results when looking at the roughness of diluted microgels (uneven shape = less spherical shape) as a function of their size in 2 different commercial yogurts. Those authors found that large microgels $\left(>30 \mu \mathrm{m} \approx 707 \mu \mathrm{m}^{2}\right)$ were rougher than small microgels $(<30 \mu \mathrm{m})$. Moussier et al. (2019) did not provide any further explanation. During processing, microgel aggregation could promote the formation of nonspherical microgels. Indeed, even if the primary microgels are perfectly spherical, for instance in rennet gels, aggregation leads to the formation of irregular clusters of protein particles (named aggregated microgels in the present study; Mellema et al., 2002). Hahn et al. (2012a) compared the shape of microgels found in cream cheeses that were tempered at $56^{\circ} \mathrm{C}$ for $60 \mathrm{~min}$ (favoring microgel aggregation) or at $38^{\circ} \mathrm{C}$ for 1 min (less favorable for microgel aggregation). Aggregation increased for the cream cheese tempered at $56^{\circ} \mathrm{C}$ for $60 \mathrm{~min}$, leading to the formation of larger microgels that were elongated and more concave.

Relationship Between Yogurt Apparent Viscosity, Syneresis, and Structure. The yogurt smoothed at $42^{\circ} \mathrm{C}$ (Y42) had significantly higher induced syneresis, microgel particle size $\mathrm{D}[4,3]$, microgel surface area, and NHI compared withY20. In addition, Y42 had a significantly lower number of microgels - especially those with a surface area smaller than $10^{3} \mu^{2}$ - and an increased number of microgels with a surface area larger than $10^{4} \mu \mathrm{m}^{2}$ compared with Y20. The higher number of large particles found in Y42 could explain that yo-

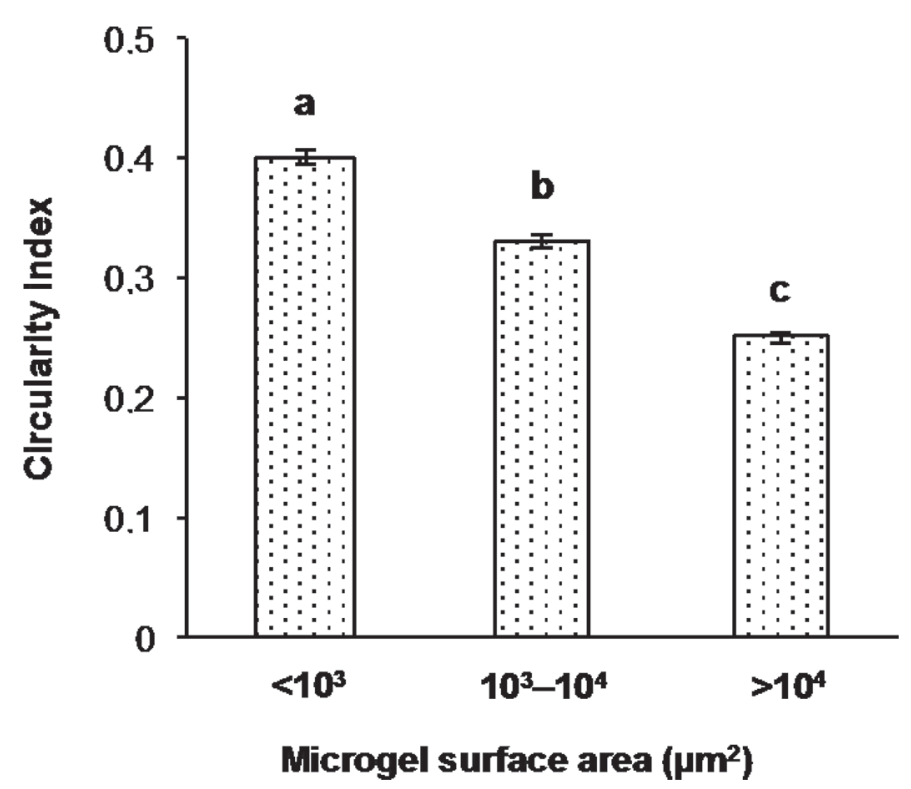

Figure 9. Microgel circularity index depending on microgel surface area class. Error bars represent the SE $(\mathrm{n}=108)$. Different letters (a, b, c) indicate statistically significant differences $(P<0.0001)$. 
gurt's higher induced syneresis value. Moreover, Y42 had the highest NHI value, indicating that Y42 had the most heterogeneous protein network gel density with more frequent empty areas, creating a porous structure that favored induced syneresis. Using sieving and image analysis of diluted yogurt in deionized water, van Marle (1998) suggested that smaller and more compact yogurt particles reduce syneresis. Körzendörfer et al. (2018) found no correlation between laser diffraction results (diameter $<0.5 \mathrm{~mm}$ ) and induced syneresis. However, the results for induced syneresis in the present study were highly correlated with (proportional to) the count of large grains (particle diameter $>0.9 \mathrm{~mm} \approx 6.4 \times$ $10^{5} \mu^{2}$ ) that were identified as microgel aggregation during process. In contrast, Rasmussen et al. (2007) showed no relationship between the degree of microgel aggregation after $7 \mathrm{~d}$ of storage and induced syneresis, which was influenced more by the yogurt composition (fat and protein contents).

We observed an increase in the number of microgels with surface areas larger than $10^{4} \mu \mathrm{m}^{2}$ after $7 \mathrm{~d}$ of storage. In addition, the surface area of the images occupied by microgels with surface areas larger than $10^{4} \mu \mathrm{m}^{2}$ was significantly higher on $\mathrm{d} 7$ than on $\mathrm{d} 0$. This difference could have been related to an aggregation phenomenon also referred to as the rebodying effect, as mentioned by Mokoonlall et al. (2016). Rebodying is usually seen as an increase in stirred gel viscoelastic properties during storage as a result of protein network reorganization (Renan et al., 2008, 2009). For instance, microgel aggregation in rennet gel is responsible for increases in elasticity during storage (Mellema et al., 2002). Because cooling induces a short-term rebodying during early storage, gel smoothing is generally performed before cooling to ensure higher firmness and viscosity in yogurt (Mokoonlall et al., 2016). Guénard-Lampron et al. (2020) compared the effect of the smoothing temperature of yogurt stirred by means of a technical-scale unit on the yogurt's rheological properties during storage $(>7 \mathrm{~d})$. Viscosity did not increase during storage whether smoothing was performed at $20^{\circ} \mathrm{C}$ or $38^{\circ} \mathrm{C}$. To our knowledge, no other studies have investigated the effect of smoothing temperature during yogurt storage, and few studies have looked at microgel aggregation during storage. Previous studies using image analysis to count microgels with a perimeter greater than $1 \mathrm{~mm}$ $\left(>318 \mu \mathrm{m}\right.$ diameter $\left.\approx 7.9 \times 10^{4} \mu \mathrm{m}^{2}\right)$ detected no aggregation during storage (Küçükçetin, 2008b; Küçükçetin et al., 2008, 2009), possibly because of the size of the microgels counted. Indeed, in our study, the count of large microgels significantly increased over time for particles between $10^{4}$ and $10^{5} \mathrm{\mu m}^{2}$, whereas the count of particles over $10^{5} \mu^{2}$ did not significantly increase over time. As no study has linked microgel aggregation and rebodying in stirred yogurt, future study is needed.

When all the results obtained in this study are considered, smoothing performed during a cooling ramp induced an intermediary behavior. Most of the time, YR was significantly different from Y20 and yielded results between those of Y42 and Y20. The YR yogurt showed significantly higher microgel particle size [D4,3], microgel surface area, and NHI compared with Y20. In addition, YR had a significantly lower number of microgels, especially of those with a surface area smaller than $10^{3} \mu^{2}$, whereas the number of microgels with a surface area larger than $10^{4} \mu \mathrm{m}^{2}$ was increased compared with Y20. At the end of the smoothing process, yogurt apparent viscosity was significantly higher for YR than for Y20, in accordance with the larger microgels. This finding might suggest that gradual cooling while smoothing could promote the formation of microgels of intermediate size (between $10^{4}$ and $10^{5}$ $\mu \mathrm{m}^{2}$ ), leading to yogurts with higher apparent viscosity but lower induced syneresis.

\section{CONCLUSIONS}

The objective of this study was to investigate, by means of laser diffraction and image analysis, the effects of smoothing temperature and WP ingredient on the formation of microgels and their behavior during storage. Temperature had an important effect on microgel structure and gel heterogeneity. A low smoothing temperature produced small particles, and a smoothing temperature of $42^{\circ} \mathrm{C}$ before storage produced a heterogeneous gel with large microgels that were probably related to higher induced syneresis. The WP ingredient had only a small influence on induced syneresis, and because the standardization was similar between the 2 formulas, the WP ingredient did not affect yogurt properties. Because the image analyses did not require any dilution of the yogurt samples, this study highlighted the aggregation of microgels during storage and the presence of a disrupted gel around them. This aggregation could be involved in the rebodying mechanism. Further research is needed to understand the different roles of the disrupted gel and the microgels in a yogurt's overall properties at a larger production scale. Microscopic image analyses of undiluted yogurt proved to be effective for describing yogurt structure at an intermediate scale (smaller than millimeters and larger than micrometers). This method also provided new indices and information such as the NHI (which is indicative of the heterogeneity of the protein network density) and microgel circularity. In comparison with laser diffraction, microscopic image analysis is cheaper 
and less time-consuming. However, combining image analysis and laser diffraction could provide further insights into microgel aggregation.

\section{ACKNOWLEDGMENTS}

This study was jointly supported by the research programs of the Fonds de recherche du Québec-Nature et technologies (FRQNT; Québec City, QC, Canada), Novalait Inc. (Québec City, QC, Canada), and the Ministère de l'Agriculture, des Pêcheries et de l'Alimentation du Québec (MAPAQ; Québec City, QC, Canada). The authors also thank Diane Gagnon and Marie-Michelle Gagnon for their technical support. The authors have not stated any conflicts of interest.

\section{REFERENCES}

Abu-Jdayil, B. 2003. Modelling the time-dependent rheological behavior of semisolid foodstuffs. J. Food Eng. 57:97-102. https://doi .org/10.1016/S0260-8774(02)00277-7.

Abu-Jdayil, B., M. S. Nasser, and M. Ghannam. 2013. Structure breakdown of stirred yoghurt in a circular pipe as affected by casein and fat content. Food Sci. Technol. Res. 19:277-286. https:// doi.org/10.3136/fstr.19.277.

Afonso, I. M., L. Hes, J. M. Maia, and L. F. Melo. 2003. Heat transfer and rheology of stirred yoghurt during cooling in plate heat exchangers. J. Food Eng. 57:179-187. https://doi.org/10.1016/S0260 -8774(02)00296-0.

Afonso, I. M., and J. M. Maia. 1999. Rheological monitoring of structure evolution and development in stirred yoghurt. J. Food Eng. 42:183-190. https://doi.org/10.1016/S0260-8774(99)00118-1.

AOAC International. 2012. Official Methods of Analysis. 19th ed. AOAC International, Gaithersburg, MD.

Arshad, M., M. Paulsson, and P. Dejmek. 1993. Rheology of buildup, breakdown, and rebodying of acid casein gels. J. Dairy Sci. 76:3310-3316. https://doi.org/10.3168/jds.S0022-0302(93)77668 -7 .

Aryana, K. J., and D. W. Olson. 2017. A 100-year review: Yogurt and other cultured dairy products. J. Dairy Sci. 100:9987-10013. https: //doi.org/10.3168/jds.2017-12981.

Barnes, H. A. 1997. Thixotropy - A review. J. Non-Newton. Fluid 70:1-33. https://doi.org/10.1016/S0377-0257(97)00004-9.

Beaulieu, M., Y. Pouliot, and M. Pouliot. 1999. Thermal aggregation of whey proteins in model solutions as affected by casein/whey protein ratios. J. Food Sci. 64:776-780. https://doi.org/10.1111/j .1365-2621.1999.tb15910.x.

Benezech, T., and J. Maingonnat. 1993. Flow properties of stirred yoghurt: Structural parameter approach in describing time dependency. J. Texture Stud. 24:455-473. https://doi.org/10.1111/ j.1745-4603.1993.tb00054.x.

Cayot, P., J.-F. Fairise, B. Colas, D. Lorient, and G. Brulé. 2003. Improvement of rheological properties of firm acid gels by skim milk heating is conserved after stirring. J. Dairy Res. 70:423-431. https: //doi.org/10.1017/S0022029903006332.

Cayot, P., F. Schenker, G. Houzé, C. Sulmont-Rossé, and B. Colas. 2008. Creaminess in relation to consistency and particle size in stirred fat-free yogurt. Int. Dairy J. 18:303-311. https://doi.org/ 10.1016/j.idairyj.2007.06.009.

Delikanli, B., and T. Ozcan. 2014. Effects of various whey proteins on the physicochemical and textural properties of set type nonfat yoghurt. Int. J. Dairy Technol. 67:495-503. https://doi.org/10.1111/ 1471-0307.12142.

Fernandes, C. S., R. Dias, J. M. Nóbrega, I. M. Afonso, L. F. Melo, and J. M. Maia. 2005. Simulation of stirred yoghurt processing in plate heat exchangers. J. Food Eng. 69:281-290. https://doi.org/ 10.1016/j.jfoodeng.2004.08.018.

Guénard-Lampron, V., D. St-Gelais, S. Villeneuve, and S. L. Turgeon. 2019. Individual and sequential effects of stirring, smoothing, and cooling on the rheological properties of nonfat yogurts stirred with a technical scale unit. J. Dairy Sci. 102:190-201. https://doi.org/ $10.3168 /$ jds.2018-14565.

Guénard-Lampron, V., D. St-Gelais, S. Villeneuve, and S. L. Turgeon. 2020. Short communication: Effect of stirring operations on changes in physical and rheological properties of nonfat yogurts during storage. J. Dairy Sci. 103:210-214. https://doi.org/10.3168/jds .2018-16434.

Hahn, C., A. Krzeminski, S. Wille, J. Weiss, and J. Hinrichs. 2012a. Simultaneous particle size and shape analysis in fermented milk products as influenced by composition and processing. Milchwissenschaft 67:6-9.

Hahn, C., M. Sramek, S. Nöbel, and J. Hinrichs. 2012b. Post-processing of concentrated fermented milk: Influence of temperature and holding time on the formation of particle clusters. Dairy Sci. Technol. 92:91-107. https://doi.org/10.1007/s13594-011-0046-1.

Hahn, C., T. Wachter, S. Nöbel, J. Weiss, H. Eibel, and J. Hinrichs. 2012c. Graininess in fresh cheese as affected by post-processing: Influence of tempering and mechanical treatment. Int. Dairy J. 26:73-77. https://doi.org/10.1016/j.idairyj.2011.12.013.

Hess, S. J., R. F. Roberts, and G. R. Ziegler. 1997. Rheological properties of nonfat yogurt stabilized using Lactobacillus delbrueckii ssp. bulgaricus producing exopolysaccharide or using commercial stabilizer systems. J. Dairy Sci. 80:252-263. https://doi.org/10.3168/ jds.S0022-0302(97)75933-2 .

Isaacs, M. 2016. National survey taps over 1,700 dietitians to predict top 2017 food trends. Today's Dietitian. Accessed Nov. 20, 2019. https://www.prnewswire.com/news-releases/national-survey-taps -over-1700-dietitians-to-predict-top-2017-food-trends-300376374 .html.

Karam, M. C., C. Gaiani, C. Hosri, J. Burgain, and J. Scher. 2013. Effect of dairy powders fortification on yogurt textural and sensorial properties: A review. J. Dairy Res. 80:400-409. https://doi.org/10 $.1017 /$ S0022029913000514.

Körzendörfer, A., P. Temme, E. Schlücker, J. Hinrichs, and S. Nöbel. 2018. Vibration-induced particle formation during yogurt fermentation-Effect of frequency and amplitude. J. Dairy Sci. 101:38663877. https://doi.org/10.3168/jds.2017-13905.

Krzeminski, A., K. Großhable, and J. Hinrichs. 2011. Structural properties of stirred yoghurt as influenced by whey proteins. Lebensm. Wiss. Technol. 44:2134-2140. https://doi.org/10.1016/j.lwt.2011 .05 .018 .

Krzeminski, A., M. Tomaschunas, E. Köhn, M. Busch-Stockfisch, J. Weiss, and J. Hinrichs. 2013. Relating creamy perception of whey protein enriched yogurt systems to instrumental data by means of multivariate data analysis. J. Food Sci. 78:S314-S319. https://doi .org/10.1111/1750-3841.12013.

Küçükçetin, A. 2008a. Effect of heat treatment and casein to whey protein ratio of skim milk on graininess and roughness of stirred yoghurt. Food Res. Int. 41:165-171. https://doi.org/10.1016/j .foodres.2007.11.003.

Küçükçetin, A. 2008b. Effect of heat treatment of skim milk and final fermentation $\mathrm{pH}$ on graininess and roughness of stirred yogurt Int. J. Dairy Technol. 61:385-390. https://doi.org/10.1111/j.1471 -0307.2008.00420.x.

Küçükçetin, A., E. M. Çomak, A. Aşci, M. Demir, and B. Sik. 2012. Effect of casein to whey protein ratio of skim milk on the physical properties of a yoghurt drink, Ayran. Milchwissenschaft 67:274276.

Küçükçetin, A., M. Demir, A. Aşci, and E. M. Çomak. 2011. Graininess and roughness of stirred yoghurt made with goat's, cow's or a mixture of goat's and cow's milk. Small Rumin. Res. 96:173-177. https://doi.org/10.1016/j.smallrumres.2010.12.003.

Küçükçetin, A., K. Weidendorfer, and J. Hinrichs. 2008. Physical properties of stirred yoghurt as influenced by the heating process of the milk. Milchwissenschaft 63:273-276. 
Küçükçetin, A., K. Weidendorfer, and J. Hinrichs. 2009. Graininess and roughness of stirred yoghurt as influenced by processing. Int. Dairy J. 19:50-55. https://doi.org/10.1016/j.idairyj.2008.07.006.

Lee, W.-J., and J. A. Lucey. 2006. Impact of gelation conditions and structural breakdown on the physical and sensory properties of stirred yogurts. J. Dairy Sci. 89:2374-2385. https://doi.org/10 .3168/jds.S0022-0302(06)72310-4.

Lee, W.-J., and J. A. Lucey. 2010. Formation and physical properties of yogurt. Asian-Australas. J. Anim. Sci. 23:1127-1136. https:// doi.org/10.5713/ajas.2010.r.05.

Lucey, J. A., and D. S. Horne. 2009. Milk salts: Technological significance. Pages 351-389 in Advanced Dairy Chemistry: Lactose, Water, Salts and Minor Constituents. Vol. 3. 3rd ed. P. L. H. McSweeney and P. F. Fox, ed. Springer, New York, NY. https://doi .org/10.1007/978-0-387-84865-5_9

Mellema, M., P. Walstra, J. H. J. van Opheusden, and T. van Vliet. 2002. Effects of structural rearrangements on the rheology of rennet-induced casein particle. Adv. Colloid Interface Sci. 98:25-50. https://doi.org/10.1016/S0001-8686(01)00089-6.

Mezger, T. G. 2006. The Rheology Handbook: For Users of Rotational and Oscillatory Rheometers. 2nd rev. ed. Vincentz Network GmbH \& Co. KG, Hannover, Germany.

Mokoonlall, A., S. Nöbel, and J. Hinrichs. 2016. Post-processing of fermented milk to stirred products: Reviewing the effects on gel structure. Trends Food Sci. Technol. 54:26-36. https://doi.org/10 $.1016 /$ j.tifs.2016.05.012.

Moussier, M., V. Guénard-Lampron, K. Lachin, G. Moulin, S. L. Turgeon, C. Michon, D. Huc-Mathis, and V. Bosc. 2019. What do stirred yogurt microgels look like? Comparison of laser diffraction, 2D dynamic image analysis and 3D reconstruction. Food Structure 20:100107. https://doi.org/10.1016/j.foostr.2019.100107.

Nöbel, S., N.-L. Ross, K. Protte, A. Körzendörfer, B. Hitzmann, and J. Hinrichs. 2016. Microgel particle formation in yogurt as influenced by sonication during fermentation. J. Food Eng. 180:29-38. https: //doi.org/10.1016/j.jfoodeng.2016.01.033.

Rasmussen, M. A., T. Janhøj, and R. Ipsen. 2007. Effect of fat, protein and shear on graininess, viscosity and syneresis in low-fat stirred yoghurt. Milchwissenschaft 62:54-58.

Renan, M., F. Guyomarc'h, V. Arnoult-Delest, D. Pâquet, G. Brulé, and M. H. Famelart. 2008. The rebodying of stirred yoghurt: In- teractions between proteins. J. Dairy Res. 75:450-456. https://doi .org/10.1017/S002202990800352X.

Renan, M., F. Guyomarc'h, V. Arnoult-Delest, D. Pâquet, G. Brulé, and M. H. Famelart. 2009. Rheological properties of stirred yoghurt as affected by gel $\mathrm{pH}$ on stirring, storage temperature and pH changes after stirring. Int. Dairy J. 19:142-148. https://doi .org/10.1016/j.idairyj.2008.09.007.

Rueden, C. T., J. Schindelin, M. C. Hiner, B. E. DeZonia, A. E. Walter, E. T. Arena, and K. W. Eliceiri. 2017. ImageJ2: ImageJ for the next generation of scientific image data. BMC Bioinformatics 18:529. https://doi.org/10.1186/s12859-017-1934-z.

Sodini, I., F. Remeuf, S. Haddad, and G. Corrieu. 2004. The relative effect of milk base, starter, and process on yogurt texture: A review. Crit. Rev. Food Sci. Nutr. 44:113-137. https://doi.org/10 $.1080 / 10408690490424793$

Tamime, A. Y., and R. K. Robinson. 2007. Tamime and Robinson's Yoghurt: Science and Technology. 3rd ed. CRC Press, Boca Raton, FL.

van Marle, M. E. 1998. Structure and rheological properties of yoghurt gels and stirred yoghurts. PhD Thesis. Universiteit Twente, Enschede, the Netherlands.

van Marle, M. E., D. van Den Ende, C. G. de Kruif, and J. Mellema. 1999. Steady-shear viscosity of stirred yogurts with varying ropiness. J. Rheol. (N.Y.N.Y.) 43:1643-1662. https://doi.org/10.1122/ 1.551065 .

Zhang, L., D. M. Folkenberg, J. M. Amigo, and R. Ipsen. 2016. Effect of exopolysaccharide-producing starter cultures and post-fermentation mechanical treatment on textural properties and microstructure of low fat yoghurt. Int. Dairy J. 53:10-19. https://doi .org/10.1016/j.idairyj.2015.09.008.

Zoon, P. 2003. Viscosity, smoothness and stability of yogurt as affected by structure and EPS functionality. Pages 280-289 in Proc. IDF Seminar on Aroma and Texture of Fermented Milk, Kolding, Denmark. International Dairy Federation, Brussels, Belgium.

\section{ORCIDS}

S. L. Turgeon ำ https://orcid.org/0000-0003-2448-2844 